\title{
Специфика городской жизни провинции Палестина в эпоху Поздней античности
}

\author{
Сухова Ж.М., Ващева И.Ю. \\ Национальный исследовательский \\ Нижегородский государственный университет им. Н.И. Лобачевского, \\ Россия, 603950, г. Нижний Новгород, пр. Гагарина, 23 \\ E-mail: zhanna-suhova@mail.ru
}

\begin{abstract}
Аннотация. Целью статьи является изучение одного из ключевых аспектов актуальной темы в историографии - особенностей городской жизни в позднеантичный период. В качестве географических рамок была выбрана территория весьма значимой для империи провинции Палестина. Изложение материала построено при помощи нарративного, сравнительноисторического, историко-генетического, синхронного и диахронного методов. Результатом исследования стало выявление таких особенностей жизни городов региона, как полиэтничность, поликонфессиональность, многоязычие, активная торговля, определённый уровень образованности жителей городов, сохранение некоторых античных традиций и сосуществование их с христианским образом жизни. Автор показывает, что в это время жизнь в городах была активной и лишь для конца эпохи свойственно некоторое «замирание» ритма городской жизни. С узко исторической точки зрения результаты могут дать существенное понимание самой позднеантичной эпохи, с прикладной - помочь взглянуть на современную ситуацию в Палестине под другим углом.
\end{abstract}

Ключевые слова: Поздняя античность, провинция Палестина, город, полиэтничность, поликонфессиональность, многоязычие, торговля, образование, античные традиции.

Для цитирования: Сухова Ж.М., Ващева И.Ю. 2021. Специфика городской жизни провинции Палестина в эпоху Поздней античности. Via in tempore. История. Политология, 48 (2): 272-283. DOI: $10.52575 / 2687-0967-2021-48-2-272-283$.

\section{Specificity of urban life in the province of Palestine in the era of Late Antiquity}

\author{
Zhanna M. Sukhova, Irina Yu. Vashcheva \\ N.I. Lobachevsky State University of Nizhni Novgorod - National Research University, \\ 23 Gagarin Avenue, Nizhni Novgorod, 603950, Russia \\ E-mail: zhanna-suhova@mail.ru
}

\begin{abstract}
The purpose of the article is to study the features of urban life in the late antique period. It is one of the key aspects of a topical theme in historical literature nowadays. The territory of the province of Palestine as important for the empire was chosen as a geographical framework. The presentation of the material is built using narrative, comparative-historical, historical-genetic, synchronous and diachronic methods. The result of the study was the identification of such features of urban life as polyethnicity, polyconfessionalism, multilingualism, active trade, a certain level of education of city residents, the preservation of some ancient traditions and their coexistence with the Christian manner of life. It is concluded that at this time the life in the cities was active and the «fading» of the rhythm of urban life was characteristiconly at the end of the period. From an academic point of view, the results can provide a significant understanding of the late antiquity, from an applied point of view, it can help to look at the modern situation in Palestine from a different angle.
\end{abstract}


Key words: Late antiquity, the province of Palestine, city, polyethnicity, polyconfessionalism, multilingualism, trade, education, ancient traditions.

For citation: Sukhova Zh.M., Vashcheva I.Yu. 2021. Specificity of urban life in the province of Palestine in the era of Late Antiquity. Via in tempore. History and political science, 48 (2): 272-283 (in Russian). DOI: $10.52575 / 2687-0967-2021-48-2-272-283$.

\section{Введение}

История поздней античности в различных её проявлениях на сегодняшний день является одной из самых актуальных и обсуждаемых в мировой историографии. Примечательно то, что исследователи определяют этот период по-разному: в зависимости от своей профессиональной специализации часть из них называют его «периодом поздней Римской империи», другие включают его в «раннее средневековье», третьи называют «ранневизантийским» или «протовизантийским» периодом [Лопатина, 2017]. Только в последние десятилетия среди работ специалистов наметилась и постепенно утверждается тенденция рассматривать данный период как самостоятельную «эпоху поздней античности» (Late Antiquity) [Ващева, 2009, с. 220], в целом заключая его в отрезок конца III - начала VII вв.

Выделение этого времени в особый период связано с рядом факторов. Традиционная историография рисует нам картину угасания и погружения в кризис всего того, что было достигнуто, завоевано, придумано, сотворено античностью; параллельно шли нашествия различных варварских племён с Севера и Востока, оставляющие после себя лишь шлейф разрушений, за чем непременно следовали «тёмные» века и средневековье. Ранее такое представление о завершении античного периода казалось логичным и понятным, а не вписывающиеся в него нарративные данные и артефакты интерпретировались как издержки «переходного периода» [Ващева, 2017, с. 5].

\section{Результаты и их обсуждение}

Начиная с 60-70-х гг. прошлого столетия в исторической литературе стали появляться работы исследователей, которые предложили новый взгляд на события данного времени [Ващева, 2009, с. 221] и которые акцентировали внимание на достаточную обеспеченность эпохи источниками - практически неосвоенными и почти не введёнными в научный оборот [Болгов, 2009, с. 4], которые уже никак нельзя было интерпретировать в качестве «издержек «переходного периода».

Одним из ключевых вопросов, ответ на который может дать существенное понимание позднеантичной эпохи, указать на её важную черту, является вопрос о жизни городов. Судьбы города на Западе и Востоке Римской империи различны. Примечательно то, что в то время как города на Западе хирели, утрачивали свое значение и исчезали с лица земли, в восточной части империи сохранилось большое число городов, которые не только играли значительную роль в социально-экономической и политической жизни империи, но и являлись центрами ремесла и торговли [Курбатов, 1962]. В особенности это касается городов ближневосточных провинций, расположенных на перекрёстке торговых, культурных путей. Накопленный исследовательский и собранный источниковый материал, а также особое значение Палестины для империи - это христианский, паломнический, образовательный центр, расположенный на торговых путях из Азии в Европу и Африку - позволяет обратить внимание и предпринять попытку изучения особенностей городской жизни именно этого региона [Sivan, 2008].

Специфика развития исторической области Палестина зависела и зависит от основ, заложенных в древности, события и процессы позднеантичного периода, происходившие на её территории, естественным образом сказались на её дальнейшей жизни. Разработка темы статьи предоставляет возможность взглянуть на современные актуальные проблемы региона с иных позиций (например, на вопрос о статусе святынь для различных религий и 
их течений на территории Палестины и конкретно города Иерусалима как Священного города, в целом на проблему отношений между различными этно-конфессиональными группами Палестины). Кроме того, в отечественном научном поле заявленная тема никогда не была предметом специального исследования.

Одним из первых отечественных учёных, который затронул проблему жизни городов Ранней Византии, был Г.Л. Курбатов в монографии «Ранневизантийский город (Антиохия в IV веке)». Несмотря на то, что он занимался изучением сирийского города, рассматривая проблему его функционирования через призму марксизма-ленинизма, он указал на невозможность изучения средневекового города (в данном случае это Антиохия) «... без более глубокого исследования внутреннего развития византийского города IV-VI вв...» [Курбатов, 1962].

Выявляя особенности городской жизни Палестины, мы в первую очередь попытаемся охарактеризовать её проявления в наиболее крупных центрах - Кесарии, Газе, Иерусалиме. Названия именно этих городов часто встречаются в нарративных источниках и при описании древними историками ключевых событий эпохи, например в «Церковной истории» Феодорита Кирского (ок. 390-457 гг.) [Тимофеев, 1993], в одноимённом труде Эрмия Созомена (ок. 400-450 гг.) [Созомен, 1851]. Кроме этого, были использованы другие источники местного происхождения, из которых мы почерпнули сведения о паломничестве и монашеской жизни и о том, как уживались классическая и формирующаяся христианская культуры в пределах городской черты, такие как жития [Помяловский, 1885; Помяловский, 1898] и поучения [Кирилл Иерусалимский, 2010].

Более скромной характеристикой удалось наделить города размером поменьше, такие как Тавааф, Анфедон, Рафия, Вефилия, Аскалон, Иоппия [Болгов, 2014, с. 40] (прибрежные города, расположенные в южной части Палестины), города близ современного Тель-Авива, например, Аполлония (Сузуса) и Ямния (он же Явне; оба - прибрежные города центральной части провинции) [Cotton, Di Segni, Eck et al., 2011; Cotton, Di Segni, Eck et al., 2014], Севастия (северная часть провинции) [Болгова, Болгов, 2018].

Нарративные сведения о религиозной и этноязыковой ситуации дополняют эпиграфические памятники, собранные в первых трёх частях Corpus Inscriptionum Iudaeae/Palestinae [Cotton, Di Segni, Eck et al., 2011; Cotton, Di Segni, Eck et al., 2012; Cotton, Di Segni, Eck et al., 2014].

Как уже было сказано, в распоряжении исследователей имеется достаточно источников, чтобы охарактеризовать крупные города провинции. C начала V в. в силу разукрупнения в регионе было создано три провинции, метрополиями которых стали Кесария, Скифополь и Газа. Иерусалим же становится центром патриархии - одной из четырех на Востоке империи.

Городом, который в силу обилия источников уже на протяжении нескольких десятилетий получает преимущественное внимание и зарубежных, и российских учёных, является Газа. Затрагивая вопросы образования, религии и культуры этого палестинского города, мы учитывали разработки Г. Дауни [Downey, 1963], Я. Чехановец [Чехановец, 2006; Tchekhanovets, 2018], А.М. Болговой [Болгова, 2011], Я.В. Манохина [Манохин, 2018], А.В. Курбанова [Курбанов, 2018], а также ознакомились с работой М. Мейера [Meyer, 1907].

Существенных результатов достигли отечественные исследователи, изучающие столицу провинции Кесарию Палестинскую. При разработке темы мы учитывали результаты работ Л. Левина [Levine, 1975], И.Ю. Ващевой [Ващева, 2005], Н.Н. Болгова [Болгов, Агаркова, 2013], а также ознакомились с выпускной квалификационной работой О.В. Бузанаковой [Бузанакова, 2017], в которой молодой учёный предприняла попытку дать комплексную характеристику города, и другие работы, затрагивающие частные проблемы городской жизни в рамках эпохи [Беневич, 2015]. 
Кроме того, мы учитывали результаты работы видного британского учёного А.Х.М. Джонса о развитии городов Востока со времён Александра Македонского до времени правления Юстиниана, у которого мы главным образом почерпнули сведения об экономическом состоянии городов империи в целом и о классическом образе жизни в них [Jones, 1940].

Опираясь на опыт исследователей, а также на источники, которые редко использовались нашими предшественниками (в основном это касается памятников эпиграфики), составим представление о том, как протекала жизнь в позднеантичных палестинских городах и попытаемся определить её характерные черты: показать «настроение», ритм городов, понять, чем жили люди в городах, кто в них проживал и на каком языке говорил, во что верили, каков был уровень их образованности, городская культура.

Изложение материала построено с помощью следующих методов:

1) нарративный метод, позволяющий описывать исторические факты, а затем их интерпретировать;

2) сравнительно-исторический метод, позволяющий, например, сравнивать данные о городах между собой и выявлять общее и специфичное;

3) историко-генетический метод позволяет исследовать происхождение и развитие того или иного рассматриваемого аспекта городской жизни, например, этноконфессиональных отношений;

4) синхронный и диахронный методы.

В первую очередь при знакомстве с нарративным и эпиграфическим материалом отмечаются упоминания о различных народах Палестины, а также языковое многообразие региона. Учитывая его историю, можно констатировать проживание здесь как минимум нескольких народов, таких как евреи, самаритяне, сирийцы, греки, римляне. Когда же христианство в империи было разрешено для свободного исповедания, Палестина постепенно начала приобретать статус Святой земли, и в качестве паломников провинцию стали посещать представители других народов и этносов, а некоторые оставались жить в городах, например, служа Господу в монастырях. Например, Иероним Стридонский (ок. 347-420 гг.) в «Письмах к Марцелле от имени Павлы и Евстохии» (Hieron. Ep. 44) [Иероним, 1884] отмечает, что для всех христиан - от британцев и галлов до армян, персов, народов Индии и Эфиопии - палестинский город Иерусалим является центром преклонения перед святынями, и все они в качестве паломников «...стекаются к этим местам... Сколько разностей народных, столько же почти и поющих хоров» (Hieron. Ep. 44). Другой древний автор Кирилл Скифопольский (ок. 524-558 гг.) вторит Иерониму [Помяловский, 1898].

Памятники эпиграфики, составленные на различных языках - от классических до разнообразных восточных [Cotton, Di Segni, Eck et al., 2011; Cotton, Di Segni, Eck et al., 2012; Cotton, Di Segni, Eck et al., 2014], - подтверждают слова древних писателей. Так, в черте позднеантичного культурного слоя Иерусалима встречаются свидетельства на латыни, греческом, еврейском, армянском, арамейском [Cotton, Di Segni, Eck et al., 2012, p. 115-116, 120-121, 123-124, 129-130, 130-133, 155-157, 245-246, 249]. Причём, например, армяне и греки, судя по местонахождению граффити, в течение V - 1-й пол. VII вв. могли проживать в монастырях вместе, каких-либо этнических различий по памятникам материальной культуры не наблюдается, а богослужение до рубежа V-VI вв. проводилось на греческом языке; только позднее в практику входит служба на армянском, и вместе с этим фиксируется тенденция к постепенному обособлению армян от греческой массы христиан [Сухова, 2020, с. 41-42]. Кроме того, отметим, что практически на протяжении всего позднеантичного периода армяне и греки проживали под духовным авторитетом Иерусалимского Патриарха. Решения Халкидонского собора (451 г.), очевидно, не сразу сказались на жизни христиан города Иерусалима, но с конца VI и к середине VII вв. вызревала и приобрела четкие контуры потребность и появилась возможность поставить над всеми 
армянами Иерусалима собственного архиепископа и организовать свою общину [Сухова, 2020, c. 38-43].

Относительно Газы Я.В. Манохин заключает, что на территории города фиксируется присутствие почти всех этносов империи и даже соседних государств: самыми многочисленными народами были греки, сирийцы, арабы-набатеи, египтяне (большинство которых были христианами) и евреи [Манохин, 2018, с. 203].

В других, меньших по размеру городах, по памятникам эпиграфики наблюдается схожая, но в более скромных масштабах ситуация: так, в районе современного Тель-Авива найдены надписи на самаритянском, на смешанном самаритянском арамейском (использовался смешанный алфавит) и греческом [Cotton, Di Segni, Eck et al., 2011, p. 7-9, 10-15], в Аполлонии - на самаритянском и греческом [Cotton, Di Segni, Eck et al., 2014, p. 6-14]; в городе Ямния (Явне) была найдена уникальная мраморная плита, написанная на смешанном самаритянском арамейском и самаритянском еврейском языке, которая, видимо, указывает на языковые заимствования, смешения, а также на греческом и латыни [Cotton, Di Segni, Eck et al., 2014, p. 158-160, 169-171].

Большая часть надписей городов составлена, конечно, на греческом языке: в первую очередь это надписи погребального характера, посвятительные надписи, строительные, кроме этого, на греческом перед христианами выступали и деятели церкви, писали свои сочинения крупные древние авторы. Трудно не согласиться с тем, что греческий язык был базовым языком общения в регионе, но вместе с этим невозможно представить, чтобы все прибывающие в страну народы, буквально каждый человек (был ли это паломник или торговец) хорошо знал греческую грамматику и структуру языка.

В последнее время в зарубежной литературе встречаются исследования, в которых разрабатывается тема феномена общения позднеантичного периода в городах и который называют «speaking» [Maxwell, 2006, p. 42-64; Уоттс, 2019, с. 306-338]. Условно под «speaking» понимается не только обмен информацией, свежими новостями и попытки договориться на разных языках, но и «говорение», культура общения городских жителей в целом. Позднеантичная эпоха насыщена значимыми политическими и религиозными для людей событиями, которые они могли обсудить, посещая многочисленные гражданские мероприятия или встретившись на рынке [Maxwell, 2006, p. 42-64]; кроме этого, города являлись носителями классической культуры и образования, в них располагались библиотеки и всевозможные школы риторские, грамматические, философские; вполне обычным было чтение проповедей, заслушивание политических объявлений, выступление философов и ораторов и другое. Городская среда формировала городского жителя, который мог выслушать и поддержать беседу на различные темы [Болгова, Болгов, 2018, с. 185]. Так, например, Иоанн Златоуст (ок. 347-407 гг.) сравнил спокойные беседы монахов на духовные темы с постоянными политическими дискуссиями и беседами о политике, которые вели его прихожане: эти разговоры казались богослову пустым занятием, но простых людей интересовали факты о неудачах, успехах и скандалах общественных деятелей [Болгова, Болгов, 2018, с. 185-193]. В «Поучениях огласительных и тайноводственных» Кирилла Иерусалимского (ок. 313-386 гг.), которые направлены на аудиторию принявших христианство и собирающих его принять, это также хорошо прослеживается [Кирилл Иерусалимский, 2010, с. 3-4, 12].

В период поздней античности палестинские города были развитыми образовательными центрами. На сегодняшний день наиболее изученным в этом отношении городом является Газа. Преподаватели Газской школы представляют собой новый тип учёного: с одной стороны, они учились и учили грамматике по Гомеру, знали и заучивали классиков и верили в ценность этого материала, с другой - они были христианами и в своих сочинениях указывали на то, что достижения классической мысли должны быть установлены в более широких рамках христианской истины, что могло служить толчком для развития образования в рамках христианства [Манохин, 2018, с. 203]. К своим трудам они привлекали представителей разных конфессий, фиксируя на письме лучшие (на их взгляд) достижения мысли обеих сторон [Ма- 
нохин, 2018, с. 203]. Известный ритор Хорикий Газский (ок. 500-590 гг.) прославлял христианских подвижников и священников за религиозное благочестие, но одновременно с этим считал, что им необходимо классическое образование [Болгов, 2014, с. 47].

Наиболее универсальным образцом специализированных высших школ признаются риторские, где в наибольшей степени сохранилась классическая традиция. Как раз в Газе и располагалась такая школа, которая была одним из самых ярких центров образованности в V-VI вв. [Болгова, Болгов, 2018, с. 185]. Обучение в подобных заведениях стоило немалых денег, позволить себе в них учиться могли в основном представители элиты, но выступления преподавателей и студентов таких школ перед публикой сказывались на взглядах и культурном уровне слушателей. На основании текстов ритора Хорикия можно заключить, что в христианской Газе образование было важной частью муниципальной жизни [Болгова, Болгов, 2018, с. 185-193]. В Газе жил и работал большой ряд интеллектуалов, оставивших множество сочинений [Болгов, 2014, с. 38-52].

Аналогичное заключение можно сделать и для других крупных городских центров, таких как Иерусалим и Кесария. Последняя, помимо того что была гражданской столицей Палестины и резиденцией епископа, являлась и центром христианской учености в течение двух столетий, с большой библиотекой, прославленной именами Оригена и Евсевия Кесарийского. Однако думается, что такое заключение можно сделать лишь для крупных центров, история которых хорошо обеспечена источниками. Для городов поменьше тоже характерен высокий уровень образованности, но в более скромных масштабах.

Из источников мы можем почерпнуть сведения о поликонфессиональности, сложности религиозной ситуации региона. Известно, что основными религиями провинции до распространения христианства были различные языческие культы, иудаизм и религия самаритян. Созомен указывает, что в Палестине находили приют представители признанных позднее христианством еретических направлений, например, арианства, что ещё больше усложняет религиозную ситуацию в провинции. Рассказывая о событиях, предшествовавших Никейскому собору (325 г.), он сообщает, что последователи Ария вместе со своим сподвижником обратились к правителю палестино-кесарийской Церкви Евсевию Памфилу и скифопольскому епископу Патрофилу с целью разрешения в рамках их епископств разрешить арианам собираться вместе и отпускать культ. Они согласились, но с условием, что ариане во всём будут подчиняться и слушаться правителя Александрийской Церкви Александра (Sozom. HE. I. 15).

Наряду с этим можно отметить ещё одну религиозную региональную особенность. Ни в одном ином регионе не сложилось такой ситуации, когда в рамках одной провинции было бы два авторитетных епископа и епархий, - Кесарийской (в столице провинции, позднее главной среди трех столиц) и Иерусалимской (в духовном центре) - что порождало соперничество между ними. Один из периодов активной борьбы приходится на время епископата Кирилла Иерусалимского, в сочинениях которого встречается иное отношение к Иерусалиму и святым местам в целом, чем у его предшественников и, в частности, у такого крупного богослова, как Евсевий Кесарийский [Walker, 1990, p. 86-89]: для Евсевия не характерно именование Иерусалима «святым городом» и приложение к нему тех мест Ветхого Завета, которые говорят о нём как о Священном городе, он сосредоточен на отдельных святынях (например, на храме Гроба Господня). В отличие от него Кирилл уже без всякого ограничения именует современный ему Иерусалим «Святым градом» [Walker, 1990, p. 86-89]. В своих проповедях в качестве аргументов в богословии или просто при оглашении в пользу христианского учения Кирилл Иерусалимский помимо цитат из Священного Писания часто приводит доводы из библейской, чаще всего новозаветной археологии, и для него, по выражению Г.И. Беневича, свидетельства библейской археологии являются своего рода пятым Евангелием [Беневич, 2015 , с. 84]. В своём сочинении, судя по его повествованию о чудесах, имевших место в Иерусалиме при явлении Креста и при неудачной попытке иудеев построить заново Храм, он придает Иерусалиму исключительное значение в духовной топографии империи; с Иеруса- 
лимом он связывает и эсхатологические чаяния, причем обращённые к ближайшему будущему [Кирилл Иерусалимский, 2010, с. 180-208]. И хотя Иерусалимский престол получил статус патриаршего только на Халкидонском соборе (451 г.), уже при Кирилле Иерусалимском осуществляется существенное возвышение значения иерусалимской кафедры и города Иерусалима в целом [Беневич, 2015, с. 84].

В прибрежных городах и в южной части страны долгое время сохраняло прочные позиции язычество. Утверждение христианства в Газе состоялось в первую очередь благодаря авторитетным и сильным личностям, таким как преп. Иларион Великий (ок. 290-х - 370-х гг.) и святитель Порфирий (2-я пол. IV - 420-е гг.). Первый вёл активную проповедническую деятельность и был авторитетным человеком в городе, но известно, что, когда преподобный покинул город в целях путешествия, язычники разрушили основанный им монастырь и перебили христиан [Манохин, 2018, с. 204]. Второй приложил все усилия для борьбы с языческой городской верхушкой Газы. Порфирий понимал, что он не мог рассчитывать исключительно на силу слова и авторитет, а также на помощь со стороны городских властей в исполнении императорских законов, согласно которым языческие храмы должны были быть закрыты, а исполнение обрядов - прекращено: язычники в Газе умело их обходили, например, договариваясь, имея солидные связи или выплачивая взятки [Downey, 1963, p. 22]. Поэтому Порфирий послал письмо к константинопольскому патриарху Иоанну Златоусту, который обеспечил выдачу специального имперского указа о том, что языческие храмы Газы должны прекратить своё функционирование. Для надёжности исполнения указа был отправлен специальный человек, и посланник действительно закрыл все храмы, кроме одного. Это была святыня Марны - бога города Газа, отождествляемого с Зевсом, и которого следовало умилостивить, если город хотел оставаться процветающим и жить в достатке. Известно, что приверженцы Марны передали посланнику взятку в таком размере, что он воздержался от закрытия языческой святыни. Тем не менее после этих событий газскому епископу всё же удалось закрыть языческий храм и на его месте построить христианский [Манохин, 2018, с. 204].

Города продолжали жить традиционной общественной жизнью: в них работали и развлекали горожан самые разнообразные заведения, такие как театры, амфитеатры, цирки, лупанарии, которые умещались в одном городе с христианскими храмами и святынями [Кирилл Иерусалимский, 2010, с. 181-208; Беневич, 2015, с. 77]; однако, например, такие мероприятия, как спортивные соревнования и гладиаторские бои, где культивировалась сила и физическая красота, постепенно исчезали с арен и тренировочных площадок [Jones, 1940, p. 254].

Несмотря на то, что в археологическом плане город Газа пока слабо изучен [Чехановец, 2006, с. 424], тем не менее мозаическая карта из Мадабы [Warland, 1999, S. 41-48] середины VI в. представляет Газу как типичный ранневизантийский «мегаполис», устроенный по римскому образцу: как минимум в городе должны быть главная улица с колоннами с севера на юг, амфитеатр и две христианские базилики. В своё время на одной из городских площадей Газы стояла видная отовсюду мраморная статуя богини Афродиты, элегантная нагота которой, по сообщениям христианских авторов, постоянно толкала верующих на преступления [Downey, 1963, p. 22].

Материальная культура Кесарии Палестинской также остаётся слабоизученной, но имеющиеся уже на сегодняшний день сведения могут дать нам первичное представление об облике города: значимыми памятниками столицы провинции в III-V вв. оставались портовая гавань, храм Августа и Ромы, акведуки, театр, ипподром и дворец управителя провинции, в котором некогда проживал царь Ирод, термы. Все эти строения - образцы классической архитектуры.

В позднеантичный период города наводнялись христианскими постройками разных масштабов: строились часовенки и крупные монастыри на частные пожертвования, возводились монументальные образцы строительства на императорские средства. Правители империи не жалели средств для строительства и нанимали самых искусных мастеров свое- 
го времени. Плодами таких усилий являются Храм Гроба Господня и Храм Богоматери в Иерусалиме. Феодорит Кирский сообщает, что Храм Гроба Господня должен был превзойти все остальные церковные постройки империи по своему великолепию, сооружен из самых драгоценных материалов и украшен наилучшим образом (Theodor. Cyrrh. HE. I. 17). Активное участие в возведении храма принимала и мать Константина - Елена, которая, будучи в преклонном возрасте, прибыла в Иерусалим для содействия строительству Храма (Theodor. Cyrrh. HE. I. 18).

Другой византийский историк Прокопий Кесарийский (ок. 500-565 гг.) сообщает о таком масштабом событии, как воздвижение храма Богоматери в Иерусалиме Юстинианом, «с которым никакой другой сравнить невозможно». Расположение храма отличает его от других построек: он стоит на самом высоком холме Иерусалима таким образом, что «... часть храма покоится на крепкой скале, часть же висит в воздухе...». Мастера, что строили его, буквально презрели препятствия природы и выстроили его по новой технике. Он также сообщает, что император на строительство и содержание этого храма средств не жалел, хотя конкретная сумма им не названа (Procop. Caes. De aed. V. 6). В целом город постепенно увеличивался в своих размерах, различные гражданские строения, подлежащие ремонту, чинились или на их месте возводились новые.

Природная среда Палестины не позволяла региону быстро обогатиться, как, например, соседнему Египту, на продаже зерна. Выращивание культур в сельской местности позволяло кормиться только жителям региона, хорошо было развито скотоводство, но солидной статьёй дохода была торговля в силу расположения провинции на ключевых сухопутных и морских торговых путях, пролегающих как с севера на юг, так и с запада на восток. Ранневизантийская Газа была одним их самых крупных торговых центров на юге Палестины [Манохин, 2018, c. 203]. Торговля была основным видом деятельности города, которая шла не только между регионами империи, но и другими государствами, расположенными далеко за её пределами: наиболее крупными торговыми партнёрами выступали Индия и Персия.

В целом будучи одной из беднейших и отдаленных провинций империи, позднеантичная Палестина постепенно стала обретать облик главного земного фокуса христианства, и городская торговля практически на протяжении всего периода поздней античности велась очень активно [Downey, 1963, p. 17].

\section{Заключение}

Таким образом, мы можем заключить, что основными характеристиками городов Палестины являются этническое, языковое и конфессиональное многообразие, постоянное посещение в целях паломничества и/или торговли представителей самых разных народов; уникальное сочетание классических традиций и достижений с завоёвывающими позиции новыми, христианскими; активная торговая жизнь; определённый уровень образованности и культура общения. Конечно, обучаться в высших образовательных заведениях, вести теологические диспуты и публично выступать в качестве философа или оратора мог не каждый житель города, но прослушать мастеров своего дела, а также поддержать беседу на политическую тему, обсудить распоряжения местных властей, решения Вселенского собора, вчерашнее представление в амфитеатре жители городов могли. Также в это время возводились монументальные памятники и находились искусные мастера, способные воплотить самые грандиозные проекты зодчества, города постепенно расширялись. Практически на протяжении всего позднеантичного периода жизнь в городе, что называется, кипела, словно в котле. Сочетание перечисленного породило время, в которое люди перемещались и проживали рядом с самыми разнообразными культурами, узнавали новое, слушали и говорили, спорили, верили. Это было время поиска истины, выработки и установления канонов и догм, время, которое показало, что регион был способен вместить в себя самые разнообразные формы религии и культы, и в этом заключается его богатство. Саму Палестину можно назвать регионом, единым в своей неоднородности. 
К концу же позднеантичной эпохи настроения жителей стали более пассивны, их уже не так сильно, как ранее, волновало происходящее вокруг, жизнь в городах постепенно замирала. Эту проблему и некоторые другие, например, вопрос, касающийся попытки выстроить типологию городов с использованием историко-типологического метода или используя подход М. Вебера об идеальном типе, ещё предстоит раскрыть более широко.

Палестина находится на перекрёстке торговых и культурных путей, издревле была наводнена разнообразными народами со своей культурой и мировоззрением и исторически является регионом контрастов, поэтому любое решение современных проблем здесь должно учитывать это многообразие культур и исторические особенности региона, сформировавшиеся много веков назад.

\section{Список сокращений:}

Hieron. Ep. - Hieronymus, Epistulae;

Procop. Caes. De aed. - Procopius Caesariensis, De aedificiis;

Sozom. HE. - Sozomenus, Historia Ecclesiastica;

Theodor. Cyrrh. HE. - Theodoretus Cyrrhensis, Historia Ecclesiastica.

\section{Список литературы}

1. Беневич Г.И. 2015. Св. Кирилл Иерусалимский и борьба за возвышение Иерусалимской кафедры в IV в. В: Научная сессия ГУАП (Санкт-Петербургский государственный университет аэрокосмического приборостроения). Сборник докладов. В 3-х частях. СПб.: 75-85.

2. Болгов Н.Н. 2009. Поздняя античность: история и культура. Белгород, 88.

3. Болгов Н.Н. 2014. Ранневизантийская Газа в Палестине: город и его писатели. В: Античная древность и средние века. Вып. 42: 38-52.

4. Болгов Н.Н., Агаркова Ю.Н. 2013. К истории Кесарии Палестинской в ранневизантийское время. В: Кондаковские чтения IV. Белгород: 78-83.

5. Болгова А.М. 2011. Хорикий из Газы: античная риторика как форма для византийской школы. В: Научные ведомости. Серия История. Политология. Экономика. Информатика. № 1 (96). Вып. 17: 48-53.

6. Болгова А.М., Болгов Н.Н. 2018. Ранневизантийская школа: античное и христианское (по Хорикию из Газы). В: Европейские традиции высшей школы в России: от доуниверситетской модели к университетам. Великий Новгород: 185-193.

7. Бузанакова О.В. 2017. Кесария Палестинская в III-V вв.: выпускная квалификационная работа: 44.03.05. Белгород, 103.

8. Ващева И.Ю. 2005. Кесария Палестинская в III - первой половине VII вв. В: Вестник ННГУ им. Н.И. Лобачевского. Серия История. Вып. 1 (4): 13-25.

9. Ващева И.Ю. 2009. Концепция поздней античности в современной исторической науке. В: Вестник Нижегородского университета им. Н.И. Лобачевского. № 6 (1): 220-231.

10. Ващева И.Ю. 2017. Средиземноморский мир в эпоху поздней античности и раннего средневековья. Нижний Новгород, 46.

11. Иероним. 1884. Творения блаженного Иеронима Стридонского. в 17-ти томах. Ч. 2. Письма № 44-86. Киев, тип. И.И. Чоколова, 430.

12. Кирилл Иерусалимский. 2010. Святитель Кирилл, архиепископ Иерусалимский. Поучения огласительные и тайноводственные. М., Благовест, 352.

13. Кондратьев С.П. (ред.). 1996. Прокопий Кесарийский. Война с готами. О постройках. М., Арктос, 917.

14. Курбанов А.В. 2018. Повседневная жизнь ранневизантийской палестинской киновии: на примере Газского монастыря аввы Серида: дисс. канд. ист. наук: 07.00.03. Белгород, 247.

15. Курбатов Г.Л. 1962. Ранневизантийский город (Антиохия в IV веке). Л., Изд-во Ленингр. ун-та, 286.

16. Лопатина М.Ю. 2017. Современная зарубежная историография истории Поздней античности и Ранней Византии (1990-2015 гг.). Белгород, 104.

17. Манохин Я.В. 2018. Ранневизантийская Газа - христианский интеллектуальный центр: дисс. канд. ист. наук: 07.00.03. Белгород, 254. 
18. Помяловский И. (ред.). 1885. Кирилл Скифопольский. Житие св. Саввы Освященного, составленное св. Кириллом Скифопольским в древнерусском переводе. В: Палестинский патерик. Вып.1. СПб., 155.

19. Помяловский И. (ред.). 1898. Кирилл Скифопольский. Житие иже во Святых отца нашего Евфимия Великого. В: Палестинский патерик. Вып. 2. СПб., 108.

20. Созомен. 1851. Эрмий Созомен Саламинский. Церковная история. СПб., Типография Э. Фишера, 636.

21. Сухова Ж.М. 2020. У истоков армянской общины в Иерусалиме в период Поздней Античности (начало V - первая половина VII вв.). В: Исторические типы человеческих сообществ: материалы I Всероссийской студенческой научной конференции «Исторические типы человеческих сообществ» (29 февраля - 1 марта). Казань: 38-43.

22. Тимофеев М.А. (ред.). 1993. Феодорит Киррский. Церковная история. М., Росспэн, 240.

23. Уоттс Э. 2019. Образование в поздней античности. Общение, мысль и социализация. B: HYPOTHEKAI. Вып. 3: 306-338.

24. Чехановец Я.М. 2006. «Marnas victus est a Christo». К вопросу о христианизации древней Газы. В: Мнемон. Вып. 5. СПб.: 419-454.

25. Ashkenazi Y. 2004. Sophists and Priests in Late Antique Gaza According to Choricius the Rhetor. In: Christian Gaza in late antiquity. Leiden, Brill: 195-208.

26. Cotton H.M., Di Segni L., Eck W. et al. 2011. Corpus Inscriptionum Iudaeae/Palestinae. Volume II: 1121-2160. Berlin/Boston, Walter de Gruyter GmbH \& Co. KG, 918.

27. Cotton H.M., Di Segni L., Eck W. et al. 2012. Corpus Inscriptionum Iudaeae/Palestinae. Volume I: Jerusalem. Part 2: 705-1120. Berlin/Boston, Walter de Gruyter GmbH \& Co. KG, 575.

28. Cotton H.M., Di Segni L., Eck W. et al. 2014. Corpus Inscriptionum Iudaeae/Palestinae. Volume III: 2161-2648. Berlin/Boston, Walter de Gruyter GmbH \& Co. KG, 738.

29. Downey G. 1963. Gaza in the Early Sixth Century. Norman, University of Oklahoma Press, $\mathrm{XV}, 172$.

30. Jones A.H.M. 1940. The Greek City from Alexander to Justinian. Oxford, 393.

31. Levine L. 1975. Caesaria under Roman Rule. Leiden, Brill, 320.

32. Maxwell J.L. Rhetoric and society: Contexts of public speaking in Late antique Antioch. In: Christianization and Communication in Late Antiquity: John Chrysostom and his Congregation in Antioch. Cambridge University Press, 2006. P. 42-64.

33. Meyer M.A. 1907. A History of the City of Gaza. New York, 182.

34. Sivan H. 2008. Palestine in Late Antiquity. Oxford, New York, 322.

35. Tchekhanovets Y. 2018. The Caucasian Archaeology of the Holy Land: Armenian, Georgian and Albanian communities between the fourth and eleventh centuries CE. Leiden - Boston, Brill, 307.

36. Walker P. 1990. Holy City Holy Places? Christian attitudes to Jerusalem and the Holy Land in the 4th century. Oxford, OUP: 86-89.

37. Warland R. 1999. Die Mosaikkarte von Madaba und ihre Kopie in der Sammlung des Archäologischen Instituts der Universität Göttingen. In: Georgia Augusta. Band. 71. Freiburg, Sonderdrucke aus der Albert-Ludwigs Universität Freiburg: 41-48.

\section{References}

1. Benevich G.I. 2015. Sv. Kirill Ierusalimskij i bor'ba za vozvyshenie Ierusalimskoj kafedry v IV v. [St. Cyril of Jerusalem and the Struggle for the Exaltation of the See of Jerusalem in 4 Century] In: Nauchnaya sessiya GUAP (Sankt-Peterburgskij gosudarstvennyj universitet aerokosmicheskogo priborostroeniya) [Scientific session of SUAI (St. Petersburg State University of Aerospace Instrumentation)]. Collection of reports. In 3 parts. St. Petersburg: 75-85 (in Russian).

2. Bolgov N.N. 2009. Pozdnyaya antichnost': istoriya i kul'tura [Late antiquity: history and culture]. Belgorod, 88 (in Russian).

3. Bolgov N.N. 2014. Rannevizantijskaya Gaza v Palestine: gorod i ego pisateli [Early Byzantine Gaza in Palestine: the city and its writers]. In: Antichnaya drevnost' i srednie veka [Ancient Antiquity and the Middle Ages]. Issue. 42: 38-52 (in Russian).

4. Bolgov N.N., Agarkova Yu.N. 2013. K istorii Kesarii Palestinskoj v rannevizantijskoe vremya [On the history of Palestinian Caesarea in early Byzantine times]. In: Kondakovskie chteniya IV [Kondakov readings 4]. Belgorod: 78-83 (in Russian). 
5. Bolgova A.M. 2011. Chorikij iz Gazy: antichnaya ritorika kak forma dlya vizantijskoj shkoly [Choricius of Gaza: Ancient Rhetoric as a Form for the Byzantine School]. In: Nauchnye vedomosti [Scientific statements]. Series History. Political Sciences. Economics. Informatics. № 1 (96). Issue. 17: 48-53 (in Russian).

6. Bolgova A.M., Bolgov N.N. 2018. Rannevizantijskaya shkola: antichnoe i hristianskoe (po Horikiyu iz Gazy) [Early Byzantine School: Antique and Christian (on Choricius from Gaza)]. In: Evropejskie tradicii vysshej shkoly v Rossii: ot douniversitetskoj modeli k universitetam [European traditions of higher education in Russia: from the pre-university model to universities]. Velikij Novgorod: 185-193 (in Russian).

7. Buzanakova O.V. 2017. Kesariya Palestinskaya v III-V vv.: vypusknaya kvalifikacionnaya rabota: 44.03.05 [Caesarea Palestinian in III-V centuries: final qualification work: 44.03.05]. Belgorod, 103 (in Russian).

8. Vashcheva I.Yu. 2005. Kesariya Palestinskaya v III - pervoj polovine VII vv. [Caesarea Palestinian in III - the first half of the VI centuries]. In: Vestnik Nizhegorodskogo gosudarstvennogo universiteta im. N.I. Lobachevskogo [Bulletin of the Lobachevsky State University of Nizhni Novgorod]. Series History. Issue 1 (4): 13-25 (in Russian).

9. Vashcheva I.Yu. 2009. Koncepciya pozdnej antichnosti v sovremennoj istoricheskij nauke [The concept of late antiquity in modern historical science]. In: Vestnik Nizhegorodskogo gosudarstvennogo universiteta im. N.I. Lobachevskogo [Bulletin of the Lobachevsky State University of Nizhni Novgorod]. № 6 (1): 220-231 (in Russian).

10. Vashcheva I.Yu. 2017. Sredizemnomorskij mir v epohu pozdnej antichnosti i rannego srednevekov'ya: uchebno-metodicheskoe posobie [Mediterranean world in the era of late antiquity and the early Middle Ages: a teaching aid]. Nizhnij Novgorod, 46 (in Russian).

11. Ieronim. 1884. Tvoreniya blazhennogo Ieronima Stridonskogo [Creations of the blessed Jerome of Stridon]. In 17 t. Part. 2. Pis'ma № 44-86 [Letters No. 44-86]. Kiev, tip. I.I. Chokolova, 430 (in Russian).

12. Kirill Ierusalimskij. 2010. Svyatitel' Kirill, arhiepiskop Ierusalimskij. Poucheniya oglasitel'nye i tajnovodstvennye [Saint Cyril, Archbishop of Jerusalem. Catechumens and secret teachings]. Moscow, Blagovest, 352 (in Russian).

13. Kondrat'ev S.P. (ed.) 1996. Prokopij Kesarijskij. Vojna s gotami. O postrojkah [Procopius of Caesarea. Goth war. About construction]. Moscow, Arktos, 917 (in Russian).

14. Kurbanov A.V. 2018. Povsednevnaya zhizn' rannevizantijskoj palestinskoj kinovii: na primere Gazskogo monastyrya avvy Serida: diss. kand. ist. nauk: 07.00 .03 [Everyday life of the early Byzantine Palestinian kinovy: the case of the Gaz monastery of Abba Serida: dissertation of candidate of historical sciences (PhD): 07.00.03]. Belgorod, 247 (in Russian).

15. Kurbatov G.L. 1962. Rannevizantijskij gorod (Antiohiya v IV veke) [Early Byzantine city (Antioch in the IV century)]. Leningrad, Izdatel'stvo Leningradskogo universiteta, 286 (in Russian).

16. Lopatina M.Yu. 2017. Sovremennaya zarubezhnaya istoriografiya istorii Pozdnej antichnosti i Rannej Vizantii (1990-2015 gg.) [Contemporary foreign historiography of the history of Late Antiquity and Early Byzantium (1990-2015)]. Belgorod, 104 (in Russian).

17. Manohin Ya.V. 2018. Rannevizantijskaya Gaza - hristianskij intellektual'nyj centr: diss. kand. ist. nauk: 07.00.03 [Early Byzantine Gaza - Christian Intellectual Center: dissertation of candidate of historical sciences (PhD): 07.00.03]. Belgorod, 254 (in Russian).

18. Pomyalovskij I. (ed.). 1885. Kirill Skifopol'skij. Zhitie sv. Savy Osvyashchennogo, sostavlennoe sv. Kirillom Skifopol'skim v drevnerusskom perevode [Cyril of Scythopolis. The life of St. Sava the Sanctified, compiled by St. Cyril of Scythopolis in Old Russian translation]. In: Palestinskij paterik [Palestinian patericon]. Issue. 1. St. Petersburg, 155 (in Russian).

19. Pomyalovskij I. (ed.). 1898. Kirill Skifopol'skij. Zhitie izhe vo Svyatyh otca nashego Evfimiya Velikogo [Cyril of Scythopolis. The life of others like the Saints of our Father Euthymius the Great]. In: Palestinskij paterik [Palestinian patericon]. Issue. 2. St. Petersburg, 108 (in Russian).

20. Sozomen. 1851. Ermij Sozomen Salaminskij. Cerkovnaya istoriya [Hermius Sozomen of Salamis. Church history]. St. Petersburg, Tipografiya E. Fishera, 636 (in Russian).

21. Suhova Zh.M. 2020. U istokov armyanskoj obshchiny v Ierusalime v period Pozdnej Antichnosti (nachalo V - pervaya polovina VII vv.) [At the origins of the Armenian community in Jerusalem during the Late Antiquity (early 5th - first half of the 7th centuries)]. In: Istoricheskie tipy chelovecheskih soobshchestv: materialy I Vserossijskoj studencheskoj nauchnoj konferencii 
«Istoricheskie tipy chelovecheskih soobshchestv» (29 fevralya - 1 marta) [Historical types of human communities: materials of the I All-Russian student scientific conference «Historical types of human communities» (February 29 - March 1)]. Kazan': 38-43 (in Russian).

22. Timofeev M.A. (ed.). 1993. Feodorit Kirrskij. Cerkovnaya istoriya [Theodoretus of Kyrrhus. Church history]. Moscow: Rosspen, 240 (in Russian).

23. Watts E. 2019. Obrazovanie v pozdnej antichnosti. Obshchenie, mysl' i socializaciya [Education in late antiquity. Communication, thought and socialization]. In: HYPOTHEKAI. Issue. 3: 306-338 (in Russian).

24. Chekhanovec YA.M. 2006. «Marnas victus est a Christo». K voprosu o hristianizacii drevnej Gazy [«Marnas victus est a Christo». On the question of the Christianization of ancient Gaza]. In: Mnemon. Issue. 5. St. Petersburg: 419-454 (in Russian).

25. Ashkenazi Y. 2004. Sophists and Priests in Late Antique Gaza According to Choricius the Rhetor. In: Christian Gaza in late antiquity. Leiden, Brill: 195-208.

26. Cotton H.M., Di Segni L., Eck W. et al. 2011. Corpus Inscriptionum Iudaeae/Palestinae. Volume II: 1121-2160. Berlin/Boston, Walter de Gruyter GmbH \& Co. KG, 918.

27. Cotton H.M., Di Segni L., Eck W. et al. 2012. Corpus Inscriptionum Iudaeae/Palestinae. Volume I: Jerusalem. Part 2: 705-1120. Berlin/Boston, Walter de Gruyter GmbH \& Co. KG, 575.

28. Cotton H.M., Di Segni L., Eck W. et al. 2014. Corpus Inscriptionum Iudaeae/Palestinae. Volume III: 2161-2648. Berlin/Boston, Walter de Gruyter GmbH \& Co. KG, 738.

29. Downey G. 1963. Gaza in the Early Sixth Century. Norman, University of Oklahoma Press, $\mathrm{XV}, 172$.

30. Jones A.H.M. 1940. The Greek City from Alexander to Justinian. Oxford, 393.

31. Levine L. 1975. Caesaria under Roman Rule. Leiden, Brill, 320.

32. Maxwell J.L. Rhetoric and society: Contexts of public speaking in Late antique Antioch. In: Christianization and Communication in Late Antiquity: John Chrysostom and his Congregation in Antioch. Cambridge University Press, 2006. P. 42-64.

33. Meyer M.A. 1907. A History of the City of Gaza. New York, 182.

34. Sivan H. 2008. Palestine in Late Antiquity. Oxford, New York, 322.

35. Tchekhanovets Y. 2018. The Caucasian Archaeology of the Holy Land: Armenian, Georgian and Albanian communities between the fourth and eleventh centuries CE. Leiden - Boston, Brill, 307.

36. Walker P. 1990. Holy City Holy Places? Christian attitudes to Jerusalem and the Holy Land in the 4th century. Oxford, OUP: 86-89.

37. Warland R. 1999. Die Mosaikkarte von Madaba und ihre Kopie in der Sammlung des Archäologischen Instituts der Universität Göttingen. In: Georgia Augusta. Band. 71. Freiburg, Sonderdrucke aus der Albert-Ludwigs Universität Freiburg: 41-48 (in German).

\section{ИНФОРМАЦИЯ ОБ АВТОРАХ}

Сухова Жанна Михайловна, магистрант кафедры средневековых цивилизаций Национального исследовательского Нижегородского государственного университета им. Н.И. Лобачевского, г. Нижний Новгород, Россия

Ващева Ирина Юрьевна, доктор исторических наук, профессор кафедры средневековых цивилизаций Национального исследовательского Нижегородского государственного университета им. Н.И. Лобачевского, г. Нижний Новгород, Россия

\section{INFORMATION ABOUT THE AUTHORS}

Zhanna M. Sukhova, master student of the Department of Medieval Civilizations of the National Research Nizhny Novgorod State University named after N.I. Lobachevsky Nizhny Novgorod, Russia

Irina Yu. Vashcheva, doctor of Historical Sciences, Professor of the Department of Medieval Civilizations of the National Research Nizhny Novgorod State University named after N.I. Lobachevsky, Nizhny Novgorod, Russia 